\title{
CHRISTIANITY AND THE INVENTION OF THE SEXUAL REVOLUTION IN BRITAIN, 1963-1967*
}

\author{
SAM BREWITT-TAYLOR \\ Lincoln College, Oxford
}

Running head: CHRISTIANITY AND SEXUAL REVOLUTION

ABSTRACT. This article argues that the myth of 'the sexual revolution', increasingly accepted in Britain’s national media between 1963 and 1967, played a central role in causing the real transformation of British sexual culture that occurred from the late 1960s. It also argues that Christian agency played an important role in the framing and the legitimation of this myth. Until 1963, British debates about sexual morality had been dominated by Christian arguments. In 1963 and 1964 the existence of a rapid, widespread, inexorable, secular, and antinomian transformation of sexual mores was prominently proclaimed by Christian commentators, who thought it an inevitable consequence of 'secularization', whereas secular commentators usually objected that this narrative was insufficiently evidenced. After its initial discussion in the mainstream media in 1965, the 'sexual revolution' narrative was increasingly articulated without explicit reference to Christianity, but it usually retained theologically-inspired structural features inherited from earlier religious discussions. In the late 1960s, elite perceptions of inexorable sexual liberalisation decisively legitimated rapid decensorship, wider access to the pill, and the reimagination of 'normal' sexual behaviour, thereby importantly shaping real popular change. In this way, Christian clergymen made a significant, early, unwitting, and hitherto unacknowledged contribution to Britain’s sexual revolution. 
The idea that Britain witnessed a 'sexual revolution' in the long 1960s is a recurrent feature of recent historiography, but it is also a cultural invention, which is older than the phenomenon it purports to describe. ${ }^{1}$ The first major declarations that 1960 s Britain was experiencing a swift, widespread, inexorable, post-religious, and anti-authoritarian 'revolution' in sexual mores appeared in 1963, and this five-propertied narrative rapidly rose to prominence. ${ }^{2}$ From 1965 ‘the so-called sexual revolution of our times’ was widely discussed in the mainstream press, and by 1967 its inevitability had entered conventional media wisdom. ${ }^{3}$ In 1970, no less than eighty per cent of NOP’s respondents agreed that 'people's attitudes towards sex in the last ten years have changed a lot'. ${ }^{4}$ The rise of these narratives is important, because they invented a revolution that had not yet happened. As the near-consensus of historical opinion now attests, the large-scale transformation of British sexual behaviour did not begin until the very last years of the 1960s, if not actually in the early 1970s. ${ }^{5}$ That transformation was especially aided by the pill, which was not widely available to the unmarried until $1968 .{ }^{6}$ Illegitimacy statistics are not a safe basis for asserting a mid-1960s sexual revolution, since the proportion of babies born to married parents in England and Wales declined by only three percentage points during the relevant period, from 94 per cent in 1960 to 91 per cent in $1967 .{ }^{7}$ For the vast majority of Britons, 'the golden age of marriage' and of courtship persisted throughout the 1960s: the trend towards early marriage did not peak until $1971 .{ }^{8}$ Although subcultures of sexual experimentation did exist, such as in central London, and possibly at Oxford and Cambridge, these were highly atypical, and were often valued by their participants partly for that reason. ${ }^{9}$ Neither Michael Schofield's The sexual behaviour of young people (1965) nor Geoffrey Gorer's Sex and marriage in England today (1971) found evidence of a behavioural revolution. ${ }^{10}$ Nor had 
there been a revolution in attitudes: ironically, widespread belief in dramatic sexual change was accompanied by significant dislike of it. In 1968, Gallup found that 49 per cent of its respondents disapproved of unmarried couples even using contraceptives, outnumbering the 37 per cent who did approve. ${ }^{11}$ In 1969, the popular sociological journal New Society found that 77 per cent of its respondents agreed that 'too much publicity is given to sex', and that only 19 per cent of its respondents disagreed; a plurality of its respondents thought permissive legislation the 'most objectionable' development of the 1960s. ${ }^{12}$ In 1970, 48 per cent of NOP’s respondents disapproved of 'changing sexual attitudes in the 1960s', outnumbering the 32 per cent who supported them. ${ }^{13}$ Attitudes towards adultery remained strongly hostile. ${ }^{14}$ The dominant popular culture of the mid-1960s extolled not promiscuity, but enduring romantic love. ${ }^{15}$ Yet mid-1960s ‘sexual revolution’ narratives typically proclaimed a total and irresistible transformation of the modern sexual landscape, often regardless of geography, class, and gender, and they usually declared this transformation to be self-evident, thus ignoring the obvious methodological difficulties involved in measuring sexual change. ${ }^{16}$ Their rapid rise to prominence is thus an important problem, not in social history, but in the elite cultural history of the early and mid-1960s.

Existing explanations of the postwar transformation of Britain’s sexual culture disagree about when it happened, how revolutionary it was, and what caused it, but they share the assumption that it was a social phenomenon, emerging inexorably from below, and they therefore explain it as a natural consequence of changes in everyday life, such as the new affluence, the pill, or the growing self-determination of 'the people'. ${ }^{17}$ Yet this social approach fails to emphasize the contingency and cultural specificity of western sexual norms, and should therefore be regarded as Eurocentric. ${ }^{18}$ As Shmuel Eisenstadt's concept of 'multiple modernities' reveals, there are no 'natural' or 'inevitable' responses to social change; the invention of new moral norms is not dictated by social conditions, nor by 
breakthroughs in contraceptive technology, but by contingent and locally-specific reconfigurations of existing cultural frameworks, which is why modern sexual cultures across the world have reacted to affluence and to the invention of the pill in so many different ways. ${ }^{19}$ Written with the intention of helping to 'provincialize' British sexual culture, this discussion begins from the Durkheimian premise that majority sexual cultures are decisively structured, not by any necessary developmental logic, but by dominant collective narratives, constantly reinforced in a society's public discourses, which authoritatively and often invisibly assert that particular sexual mores are historically inevitable, and that other particular sexual mores are wicked. ${ }^{20}$ On this view, there is a necessary power inequality between a society’s hegemonic cultural narratives and its ordinary people. ${ }^{21}$ Individual events are less culturally influential than the dominant narratives which interpret them, and no event can cause a society suddenly to abandon long-standing and deeply-rooted moral codes unless it can trigger a transformation in that society’s relevant self-narrative. ${ }^{22}$ Consequently, Britain’s ‘1960s sexual revolution’ should not be understood as an inevitable social development, but as an enacted narrative, whose authoritative narration in the mid-1960s was a necessary precondition of its widespread enactment from the late $1960 \mathrm{~s} .{ }^{23}$ Explanations of that revolution should not assume a teleology of unstoppable sexual liberalisation, but should instead uncover that teleology's invention, examining how it was invented, how it achieved cultural authority, how it smashed the power of long-standing taboos, and how it laid down a new and widely-shared vision of 'normal' British sexual behaviour. ${ }^{24}$

This article therefore offers an account of the invention, authorization, and impact of narratives of rapid heterosexual liberalisation in 1960s Britain, focusing on their crucial formative years between 1963 and 1967. It draws on newspapers, magazines, and major books on the subject, admittedly privileging national over international and local discussion. It finds that discourses of sexual change in mid-1960s Britain were extremely complex, and 
were prompted by a wide range of developments, including the perceived implications of 'affluence', youth culture, trends in wider cultural authority, particular scandals, ‘Americanization', and the pill. Nonetheless, inspired by the 'religious turn' in women's history, and the nascent 'postsecular turn' in the history of modern sexuality, its chief purpose is to highlight the important role of Christian agency in the framing of postwar sexual change as a widespread, unstoppable, antinomian, and post-religious 'revolution', and its significant role in the authorization of this framing. ${ }^{25}$ Christianity was the leading moral ideology in late 1950s and early 1960s Britain at both elite and popular levels, a point especially underlined by the Cold War, and mainstream British discourses about sexual morality had long been monopolized by Christian ideas. ${ }^{26}$ This cultural context allowed Christian commentators to shape the early stages of the invention of Britain’s 'sexual revolution’ narrative in significant ways.

This contention rests on four supporting claims. First, at the dawn of the 1960s the dominant culture of Christian moral authority gave radical Christian clergymen significantly more scope to publicize new narratives about sexual morality than it gave to non-Christian moral radicals, who still risked being vilified and silenced. ${ }^{27}$ Second, the deeply-rooted intertwining of Christianity and British national identity meant that the plausibility of mid1960s ‘sexual revolution’ narratives required a Christian reimagination of Britain as a 'secular society', which was achieved from $1963 .{ }^{28}$ Before 1963 , declarations of sexual transformation were consistently dismissed as incredible; early such narratives frequently justified themselves primarily by appealing to the imagined collapse of religion. Third, in 1963 and 1964 the narrative of a widespread, unstoppable and antinomian transformation of British sexual mores was prominently publicized by Christian commentators, initially radicals and then conservatives, at a time when secular commentators, lacking the theoretical rationale derived from narratives of religious crisis, usually criticised narratives of sexual 
transformation as inadequately evidenced. In the mid-1960s, these Christian interventions were thought to be important: in 1966, for example, Playboy magazine wrote to John Robinson, the Anglican bishop of Woolwich, telling him that his slipped disc, which had given him time to write Honest to God (1963), 'has made a greater contribution to western civilization than any inadvertent occurrence since the apple fell on Newton's head' ${ }^{29}$ Consequently, the early examples of 'sexual revolution' narratives in the British media often drew substantially on Christian discourses of moral revolution. Fourth, whilst from 1965 the rise of Christian ‘secularization’ narratives ensured that Britain’s ‘sexual revolution’ teleology was increasingly articulated without reference to religion, that teleology was still framed using many of the theologically-inspired structural features which it had acquired in earlier Christian discussions. Between 1965 and 1967 it was often imagined as a total and inexorable transformation which would pervade modern society from top to bottom, regardless of class, gender, or geography, and sometimes even age, primarily because this unempirical vision reflected the eschatological narratives of moral transformation employed by Christian commentators between 1963 and $1965 .{ }^{30}$ It was in this period that the presentday memory of ‘the 1960s sexual revolution' as a real, popular, and post-religious transformation was constructed.

Finally, this article argues that the rise of myths of rapid sexual liberalisation in the mid-1960s was a central cause of the real transformation of British sexual culture that began in the late 1960s. ${ }^{31}$ By transforming elite perceptions of popular trends, they made very substantial contributions towards the rapid advance of decensorship, the widespread availability of the pill, and the reimagination of modern sexual norms. In these ways, the contingent narrative of Britain’s unstoppable ‘sexual revolution’ was invented, authorized, and made self-fulfilling. 
Between the late 1830s and the early 1960s, British sexual modernity was routinely imagined as exceptionally puritanical, reticent, and Christian. ${ }^{32}$ This dominant collective moral framework was always evolving, but it consistently placed important limits on the public acceptability of non-Christian sexual radicalism. ${ }^{33}$ International coteries of modernist and Marxist intellectuals developed the idea of a 'sexual revolution' in the 1920s, for example, but in Britain their views remained the preserve of a tiny radical minority; mainstream British interpretations of Freudianism tended to leave its more radical implications unexplored until the 1970s. ${ }^{34}$ It was Christians such as A. Herbert Gray, co-founder of the National Marriage Guidance Council, who 'exercised a virtual monopoly over marriage and sex manuals in the half century following the First World War'; the ideas of non-Christian sexual radicals such as Dora Russell, Bertrand Russell, and Henry Havelock Ellis only became widely accepted if popularized in more moderate form by Christian writers. ${ }^{35}$ During the interwar period new practices such as 'dating', petting, and courting in semi-public spaces became increasingly commonplace, but pre-marital sexual intercourse remained taboo. ${ }^{36}$ Following the taboodestabilizing experience of mass mobilization during the Second World War, postwar British sexual culture evolved towards a newly-imagined 'normality' of near-universal marriage, and marriage at an increasingly young age. ${ }^{37}$ This postwar iteration of 'conservative modernity' extolled romantic love, seeing it as necessary for a fulfilled life, and as inevitably finding its ultimate expression in marriage. ${ }^{38}$ It celebrated sexual pleasure within marriage as an integral part of that love, but insisted on those pleasures being enjoyed in strict privacy, maintaining the longstanding and deeply-rooted taboos surrounding the exposure of the British body. ${ }^{39}$ Compared to its interwar predecessor, it witnessed increasing acceptance and use of contraception, although the dominant method of birth control continued to be withdrawal. ${ }^{40}$ 
Sex surveys were increasingly discussed in the national press, but these discussions had to be presented as responsible journalism, in an age when perceived obscenity was energetically prosecuted. ${ }^{41}$ In short, whilst the 'culture of restraint' evolved during the 1950 s and early 1960s, it did not collapse. ${ }^{42}$

That culture was strengthened by the individual and collective self-identification of the majority of the British population as characteristically Christian. ${ }^{43}$ This deeply-rooted component of British moral identity dated to Britain’s inception in 1707, and it continued throughout the 1960s. ${ }^{44}$ Early 1960s polls routinely found that 90 per cent of Britons claimed a Christian religious affiliation, and that only five or six per cent claimed no religious affiliation. ${ }^{45}$ Mid-1960s polls found that 80 per cent of respondents thought that Britain was a Christian country, and thought it important that it should remain so, and these numbers declined only gradually into the 1970 s and $1980 s .{ }^{46}$ Congregations had been declining since the 1920s, but the churches retained ‘a vast outer constituency of adult membership', and majorities continued to turn out for Christian rites of passage. ${ }^{47}$ As late as 1959 , atheists still faced significant popular prejudice, partly as a consequence of the religious dimension of the Cold War. ${ }^{48}$ Britain’s moral elites reimagined Britain as a post-religious society in the early 1960s, but this idea filtered only slowly to the wider populace. ${ }^{49}$

Consequently, the interwar taboos protecting the assumption that national discussions of sexual morality should be conducted within a Christian framework remained intact until the early 1960s. ${ }^{50}$ In November 1962, for example, the Times Educational Supplement could contextualize a controversial editorial on the subject by flatly stating that 'our discussion is one among Christians'. ${ }^{51}$ In 1959, conversely, the Scottish psychiatrist and 'dissident Christian’ Eustace Chesser wrote an article in the British Medical Association’s Getting Married annual apparently condoning sex before marriage, but the BMA was forced to withdraw the pamphlet after heated protests in the tabloid press. The incident concluded with 
Chesser's resignation from the BMA. ${ }^{52}$ As Hera Cook observes, 'in 1960, a medical expert could not publicly hold such a position' ${ }^{53}$

Consequently, it was radically-minded clergymen who took the lead in challenging the blanket prohibition on pre-marital sex in the early 1960s, advocating what their critics called ‘the new morality'. ${ }^{54}$ In October 1961, Harry Williams, dean of Trinity College, Cambridge, controversially argued on Meeting point, the BBC's flagship religious discussion programme, that a blanket prohibition on pre-marital sex was theologically untenable, because the true Christian position always prioritized human love over inflexible moral codes. ${ }^{55}$ By contrast with Chesser, Williams’s clerical status allowed him to make this argument with relative impunity, and he went on to become a mid-rank media figure. ${ }^{56}$ In February 1963 an independent group of Quakers released the widely-discussed Towards a Quaker view of sex report. This 'reject[ed] almost completely the traditional approach of the organized Christian church to morality', and also did so by arguing on theological grounds that Christians should always promote love. ${ }^{57}$

In this religion-dominated discussion, even secular figures who wished to liberalize British sexual culture usually found it expedient to employ Christian arguments. In November 1960 the defence team at the Lady Chatterley trial recruited a raft of clergymen to testify to that book's essential morality, and statements to this effect from John Robinson, the Anglican bishop of Woolwich, featured prominently in the trial's coverage. ${ }^{58}$ In 1962, in his controversial Reith lectures, the psychiatrist G. M. Carstairs deliberately defended premarital sex by arguing from the New Testament. 'Sexual restraint', he stated, 'was not emphasized in Christ's own teaching. For Him, the cardinal virtue was charity, that is consideration of and concern for other people'. ${ }^{59}$ In July 1963 the Conservative minister of education, Edward Boyle, reportedly 'a Christian of liberal views', adopted a similar strategy when defending his controversial principal medical officer, Peter Henderson, who was facing a barrage of 
tabloid criticism for suggesting that pre-marital sex might not always be immoral. ${ }^{60}$ Henderson had been 'bearing in mind... the words of the New Testament', Boyle explained, noting that 'views very similar to those of Dr Henderson have only recently been expressed at a churchmen's conference' ${ }^{61}$ Shortly afterwards, Gallup found that 17 per cent of its sample agreed with Henderson's comments, but that 66 per cent disagreed with them. ${ }^{62}$ The first major explicitly atheist intervention in these early 1960s discussions only occurred in July 1963, when the poet and psychiatrist Alex Comfort argued on BBC television that sex was morally analogous to sport. His ideas were narrated as highly unusual, even by those who were sympathetic to them. ${ }^{63}$

In this imaginedly Christian context, there were few theoretical reasons for proclaiming a 'sexual revolution'. Since the late 1950s it had been commonplace to assert that British society was rapidly changing, but these visions of the ‘new Britain’ usually limited themselves to economic modernization, whose social consequences were often narrated as involving greater conformity. ${ }^{64}$ The arrival of 'affluence', widely discussed since 1958, did not prompt an immediate reimagination of British sexual culture. ${ }^{65}$ It did provoke fears about teenage delinquency, but these tended to focus on violence rather than sex, a balance of concerns reflected in the 1960 Albemarle report on the youth service in England and Wales. ${ }^{66}$ Similarly, early 1960s discussions of 'the permissive society' primarily referred to issues of authority and deference, rather than specifically to sex, as was the case later in the decade. ${ }^{67}$ Popular newspapers could still reinforce perceptions of intrinsic British sexual conservatism by contrasting it with racial stereotypes of immigrant promiscuity. ${ }^{68}$

Against this backdrop, the narratives of sexual crisis that did exist tended to be narratives of crisis only, not teleologies of inexorable revolution; more importantly, they were vigorously contested, preventing them from becoming the dominant narrative. In April 1960, the social anthropologist Fernando Henriques identified a widespread youthful revolt 
against the traditional moral code, but this assessment was influentially challenged by Teenage morals (1961), published by the professional journal Education. ${ }^{69}$ Teenage morals came complete with a foreword written by the minister of education, who hailed it as a 'valuable contribution', which he hoped would be 'widely read' ${ }^{70}$ Assuming that Britain was a Christian culture, Education had commissioned two clergymen amongst its six contributors: as the various claims to expertise were listed, 'parish priest' sat alongside 'sociologist', 'anthropologist', and 'psychologist'. ${ }^{71}$ Teenage morals' introduction argued that 'a moment or two's reflection should be enough to dispose of the notion that there has been any cataclysmic change in moral standards between the present generation of teenagers and those immediately before them', and this robustly sceptical line reflected the views of its contributors. $^{72}$ The sociologist William Watson, for example, argued that alarmist press reports were 'wrapped in hoary myth and prejudice, and are contradicted by the behaviour of the great majority of young people'. ${ }^{73}$ In a similar pattern, in September 1961 the Methodist leader Leslie Weatherhead sparked off a heated debate in The Times by complaining that Britain was 'a nation in danger' due to 'sexual depravity', but the ensuing correspondence repeatedly cast doubt on his statistics. ${ }^{74}$ In a third example, Carstairs’s 1962 Reith lectures controversially suggested that young people were 'rapidly turning our own society into one in which sexual experience... is becoming accepted as a sensible preliminary to marriage', but this assessment was also widely rejected. ${ }^{75}$ The sociologist Barbara Wootton accused Carstairs of 'indulg[ing] in wide-ranging speculations without adducing more than the slenderest evidence of their validity'. ${ }^{76}$ The sociologist A.H. Halsey dismissed him as having 'run the risk of conveying a bizarre impression of British life'. ${ }^{77}$ In May 1963, writing in New Society, Carstairs conceded the unpopularity of his assessment under the headline 'People bite professor'. ${ }^{78}$ Strikingly, Carstairs had provoked this response whilst offering an assessment that fell far short of asserting a sexual revolution. He had discussed sex between 
partners would later marry each other, intending 'by no means to prophesy an era of free love, nor even an ever-increasing tolerance of casualness in sex matters'. ${ }^{79}$ In the wake of this episode, a rash of newspaper and magazine articles appeared in early 1963 with titles such as 'Is Chastity outmoded?', and ‘Are virgins obsolete?', but these answered their own questions in the negative. ${ }^{80}$ Following the Profumo scandal of summer 1963, most British commentators were quick to identify London's underworld as nationally exceptional; in the leading example, Harold Wilson pointedly contrasted metropolitan sexual decadence with his own programme for technological modernisation. ${ }^{81}$ 'Out goes the hedonist', declared the trend-following Queen magazine in September 1963, the initiative having apparently been seized by the 'technocrat with clear eyes and clinical mood' ${ }^{82}$ In December $1963 \mathrm{New}$ Society specifically denied that London was witnessing ‘a dramatic upward swing in “immoral relationships”, arguing that this was 'largely a factor of imagination' ${ }^{83}$ In a final example, the British Medical Association’s March 1964 report on Venereal disease and young people bemoaned an apparently alarming rise in promiscuity, but was, again, widely accused of being a poor piece of sociology. ${ }^{84}$

III

In 1963 and 1964, the imagined moral context framing these discussions abruptly changed. Britain was rapidly reimagined in the mainstream media as a 'secular society', in a move initiated by Christian journalists and clergymen. ${ }^{85}$ Since narratives of enduring British sexual conservatism had historically gained authority from narratives of enduring British Christianity, this sudden reimagination of British religiosity made existing narratives about British sexual culture unusually vulnerable to reformulation. ${ }^{86}$ 
The idea that a permanent 'revolution' in British moral culture was necessarily occurring due to 'secularization' made its first major appearance in Honest to God by John Robinson, the bishop and radical theologian, which was published in March 1963. This sold over a million copies, and confirmed the fame of its author. ${ }^{87}$ Initial reaction to the book focused on its apparent denial of the existence of God; it was only from the summer of 1963, in the wake of the Profumo scandal, that its ethical arguments were widely discussed. ${ }^{88}$ For this article's purposes, Honest to God's significance lies in the fact that it asserted a teleology of antinomian moral transformation, broader than a transformation of sexual morality but expressly including it, which was elaborated by a wide range of clerical writers in 1963 and 1964. ${ }^{89}$ It spoke of 'the revolution in ethics' rather than 'the sexual revolution', but contemporaries nonetheless thought that it had important implications for discussions of sexual morality; it was primarily because of Honest to God, for example, that Robinson was invited to stay at Hugh Hefner's Playboy mansion in $1969 .{ }^{90}$

Honest to God's central argument was that, due to the inevitable process of ‘secularization', ‘modern man’ no longer believed in the theistic God, thus forcing Christians to reformulate their faith for the secular modern age. ${ }^{91}$ In his sixth chapter, provocatively entitled “"The new morality”, Robinson laid out the ethical implication of this apparently rapid rise of atheism: that there was now a 'revolution in ethics', a mass rejection of traditional moral codes in favour of unrestricted human love.

There is no need to prove that a revolution is required in morals. It has long since broken out; and it is no "reluctant revolution". The wind of change is here at a gale. Our only task is to relate it correctly to the previous revolution we have described, and to try to discern what should be the Christian attitude to it. ${ }^{92}$

Robinson then illustrated his apparently self-evident 'revolution in ethics' with reference to 'sex relations before marriage' and divorce, but with the implication that it extended much more widely. ${ }^{93}$ He concluded that Christians should abandon the traditional insistence on 
divine prohibitions, and should instead prioritize human love over everything else. ${ }^{94}$ In less public contexts, Robinson was prepared to go much further: speaking at Cornell University in 1964, he predicted and refused to condemn the partial sexualisation of all human friendships. ${ }^{95}$ As he later explained, his vision of secular moral transformation was primarily inspired by his highly realized vision of Christian eschatology, which saw 'secularization' as part of a divinely-ordained transformation of the modern world. ${ }^{96}$

Robinson’s critics usually read his arguments as evidence of a straightforward intellectual surrender to secularism, but his eschatology had in fact structured his imagined 'revolution in ethics' in important ways. Unwittingly echoing a long line of examples from the Christian millenarian tradition, Robinson’s framework characterized the moral ‘revolution’ as anti-authoritarian and antinomian, enabling 'personal freedom’ from all external constraints, rather than as a replacement of one set of social expectations for another. ${ }^{97}$ Since it relied on the eschatological idea that humanity was moving to a fundamentally new age in its spiritual development, Robinson’s revolution was demographically and geographically total, structurally inhibited from complicating by age, gender, race, class, region, or culture, thus ensuring that its generalisations about 'modern man' were deeply Eurocentric. ${ }^{98}$ Since it was the product of an eschatological teleology, Robinson's narrative expressly declared that the moral revolution was both inexorable and permanent, thereby distinguishing itself from earlier discourses of moral panic, which had usually called for conservative resistance. ${ }^{99}$ For the same reason, it held 'the revolution in ethics’ to be self-evident, explicitly stating that empirical verification was unnecessary. ${ }^{100}$ Finally, Robinson's eschatology ensured that the imagined causes of his 'ethical revolution' were completely structural. Unlike the Leninist and modernist traditions which had explored ideas of ‘sexual revolution' in the 1920s, Robinson's 'revolution’ did not privilege the 
agency of a vanguard of moral revolutionaries, because he imagined it to be rooted in divine providence. $^{101}$

Perhaps unsurprisingly, Robinson's vision of dramatic moral revolution bears little relationship to the gradualist, class-differentiated and geographically fractured picture of social change now being revealed by revisionist social historians. ${ }^{102}$ Popular music was not overtly sexualized in the late 1950s and early 1960s, as it later became: early Beatles lyrics were relatively innocent, Elvis cultivated ‘a more family-orientated image’ after 1960, Bill Haley presented himself as a family man, and rock 'n' roll enjoyed substantial levels of cross-generational support. ${ }^{103}$ Social investigators found that most young people were still ‘very shy’ when discussing sex. ${ }^{104}$ The myth of 'Swinging London' had not yet been invented, and its reality only ever involved a small minority. ${ }^{105}$ Miniskirts were unknown until August 1965, and the first 'recognizably modern pornography' did not appear until late 1964. ${ }^{106}$ The recent generation of girls’ magazines, such as Roxy (1958) and Boyfriend (1959) were careful to keep in line with traditional values. ${ }^{107}$ At least one major advice column, Mary Grant's in Woman’s Own, barely changed its moral stance between 1955 and 1964; in 1966 it was still possible for the novelist Gillian Tindall to attack advice columns in general for not having changed substantially since the mid-1950s. ${ }^{108}$ Responsive to their customers, popular newspapers only rarely published explicit photographs, a situation which only changed after Rupert Murdoch purchased the Sun in 1969. ${ }^{109}$ Until the late 1960s Mills \& Boon novels did not contain premarital sex, so as 'not to offend the readership'. ${ }^{110}$ Indeed, in the 1950s it had been widely expected that, in the future, sexual mores would be more conservative, and confident statements of this assumption appeared in the British press as late as 1963, including by the sociologist Ferdynand Zweig. ${ }^{111}$

Nonetheless, between 1963 and 1965 Robinson's idea of a 'revolution in ethics' was developed and amplified by a range of radical Anglican thinkers, some of whom had already 
played a central role in advocating the so-called 'new morality' ${ }^{112}$ These successor narratives often followed Robinson by identifying a revolutionary collapse of all moral laws, including those concerning sexual behaviour. ${ }^{113}$ In January 1964, for example, the radical theologian and industrial chemist John Wren-Lewis gave a BBC lecture hailing 'the passing of puritanism and the revolution in ethics it implies, whereby physical pleasure becomes a good in itself' on eschatological grounds. ${ }^{114}$ In the same year, the prolific author and sub-dean of Winchester, Roger Lloyd, argued that 'the revolt against the traditional morality has now gone so far that we cannot ignore it', for, whilst 'most people are content to abide by the old rules, it seems certain that their number will grow less and less as time goes on', there being a general 'defiance of legality... everywhere'. ${ }^{115}$ Most famously, Honest to God's account of personal morality was followed by Douglas Rhymes’s No new morality: Christian personal values and sexual morality (1964). ${ }^{116}$ Rhymes was one of Robinson's colleagues in the diocese of Southwark, and a collaborator in Robinson's Southwark Ordination Course. ${ }^{117}$ Rhymes argued that ‘traditional morality’ was ‘to-day being rejected on all sides, and especially among the younger generation’; 'increasing sexual promiscuity and experimentation' was now being caused by a range of factors, including affluence, modern technology, and by the arrival of 'the secular society'. ${ }^{118}$ Whereas Rhymes differed from Robinson by focussing on generational differences, he followed Robinson by insisting that the new antinomianism was unavoidable. 'We may wish that it were not so; but nothing will alter the fact that it is so'. ${ }^{119}$ Rhymes's arguments were prominently reported in the press and on television; his earlier statement that 'the moral code of today is being ignored because it is already out-dated' was especially widely quoted. ${ }^{120}$ Similarly, in February 1965 Howard Root, dean of Emmanuel College, Cambridge, gave a lecture on 'love and sexual morality' which was reported at some length in The Times. This declared that 'attitudes to morals are at 
present undergoing vast changes'. Present-day society was, he said, 'living in the middle of some sort of revolution'. ${ }^{121}$

These narratives of a swift and permanent rise of antinomianism, including sexual antinomianism, were immediately strengthened by socially conservative Christian commentators, who accepted the theologically radical diagnosis of the collapse of religion, the collapse of authority, and consequent widespread sexual change, whilst abhorring these imagined developments, thus embracing what David Goodhew has called 'an eschatology of decline'. ${ }^{122}$ In 1963, for example, the journalist and Moral Re-Armament activist Peter Howard complained that 'we are no longer a Christian country', that 'most people have rejected the yardstick of absolute moral standards', and that consequently 'sexual behaviour is only one part of the landslide that has happened to our values in Britain’. ${ }^{123}$ In 1965, similarly, Geoffrey Bentley, a canon of Windsor, argued in God and Venus: an essay on sex that 'the Church is finding itself confronted... by a society which organizes itself without reference to God', and that therefore 'the traditional pattern of sexual life' was 'increasingly rejected both in theory and practice'. ${ }^{124}$ In his contribution to the 1965 anthology Sexual morality, Bentley wrote further of an apparently 'widespread' sexual ferment which 'followed the Second World War and continues today', underpinning it with more general narratives of youthful decadence. 'CND, breaking up railway carriages and having sex as a matter of course', he complained, 'all seem to be manifestations of the same antipathy to the Establishment'. ${ }^{125}$ Other conservative moralists, especially in the Daily Express, identified the so-called 'new morality' of Williams, Robinson and Rhymes as evidence of a major turning-point in moral standards. ${ }^{126}$ Roman Catholic marriage advice literature also began to engage with what it perceived to be the changing mores of the wider populace. ${ }^{127}$ At the same time, this near-consensus of elite Christian opinion was contested by populist Christian figures such as Mary Whitehouse, who consistently claimed to speak for a traditionalist 
populace. ${ }^{128}$ In 1965, for example, she complained in the Daily Mirror about 'the BBC forcing this so-called New Morality on people who don't want it or need it - and believe me, that's a majority'. ${ }^{129}$

Yet this Christian identification of an unstoppable transformation of British sexual culture, reasonably commonplace by 1963 and 1964, did not enjoy immediate support from most secular commentators. This was partly because the emerging critics of Christian sexual culture still imagined themselves as a minority, partly because they lacked a theoretical rationale for imagining an unstoppable moral revolution, and partly because they correctly realized that the current state of British sociology offered no basis for asserting such a narrative. ${ }^{130}$ As the chief medical officer of the ministry of education had observed in 1962 , 'there is no conclusive evidence that intercourse before, or outside, wedlock is on the increase. It may, or may not be so: we simply do not know' ${ }^{131}$ In May 1963, writing a humanist Decalogue for New Society, the sociologist Ronald Fletcher rejected religious rules about sex, but also cast doubt on the 'revolution' narrative by stating that 'it is by no means certain that young people of today are more given to sexual licence... than young people of earlier times'. ${ }^{132}$ Contributing to the 'Suicide of a nation?' edition of Encounter in July 1963, the psychiatrist Alan McGlashan took a less nuanced approach, bemoaning 'a society (and in particular a popular Press) which has lost touch with Eros'. ${ }^{133}$ Even Alex Comfort, one of the most radical of the new secular commentators, did not think that a sexual revolution had actually happened. ${ }^{134}$ His Sex in society (1963) suggested that young people were simply adopting adult roles earlier in life, citing Teenage morals to this effect. ${ }^{135}$ Reviewing Michael Schofield's The sexual behaviour of young people in 1965, Comfort argued that 'whether the habits of youth have changed since Chaucer is a matter of opinion'; in his view, in all respects 'save candour', 'the behaviour of the young unmarried appears to differ little from that of their elders'. ${ }^{136}$ Writing on teenage sexual behaviour for the Observer, the atheist 
writer and broadcaster Marghanita Laski took a similarly cautious line, demanding that further studies be carried out. 'What we badly need to know,' she wrote, 'is the trend'. ${ }^{137}$ Others simply assumed the absence of a revolution. In 1965 the Labour peer Wayland Young published Eros denied, which was reported as 'probably the most outspoken attack on sexual puritanism ever published in this country', but which complained that 'many, perhaps even most' Westerners 'spend their whole lives in hesitation and confusion about sex and love'. 138 In the same year Eustace Chesser’s Unmarried love scathingly attacked ‘the Victorian Family', and proclaimed that religious rules 'carry no conviction', but nonetheless treated the term 'sexual revolution' with caution, again citing Teenage morals to argue that youth were no more licentious than their elders. ${ }^{139}$ Even Penthouse's inaugural symposium on 'the sexual revolution', published with great fanfare in March 1965, failed to reach a consensus on that revolution's existence. ${ }^{140}$

In the spring and summer of 1965 the idea of an unstoppable 'sexual revolution' began to be discussed in Britain’s mainstream media, and by 1967 its media presence had become firmly established. This development was a genuine turning-point in twentieth-century British sexual history: it made inexorable liberalization the dominant public narrative about British sexual culture. This narrative shift was accomplished partly through simple repetition, partly because the apparent 'secularization' of society was now taken for granted, and partly because the narrative gained credibility from other imagined 'revolutions', such as those in living standards, leisure, and youth culture. ${ }^{141}$ It also followed a series of prominent such declarations in the American media in 1964, which had also drawn on religious discourses of rapid sexual change. ${ }^{142}$ In Britain, nonetheless, the early examples of the 'sexual revolution' 
narrative in the mainstream media drew on radical Christian ideas more frequently than they drew on narratives of Americanization. ${ }^{143}$ After the first few repetitions, however, these Christian framing discourses began to disappear from view, as the Christian narrative of ‘secularization' increasingly reconfigured the debate.

In November 1964, the first issue of King, the first of the new wave of British pornographic men’s magazines, ran a feature by the Irish journalist Brian Inglis on 'Sex and society in the sixties'. ${ }^{144}$ Inglis immediately placed movements for 'sexual revolution' in the context of secularization, arguing that, in modern times, 'it was no longer necessary to fear eternal torments in the next world as the price of fornication in this'. After multiple false starts in the interwar and immediate postwar periods, he declared, economic prosperity had finally ensured that “"free love”' was 'rapidly becoming a national habit'. ${ }^{145}$ Yet when considering the moralities which might underpin this new sexual culture, Inglis emphasized the importance of 'basically a Christian attitude - only New, rather than Old Testament': the moral demand that 'sexual intercourse' should be 'bound up' with 'affection and love'. 'It is therefore essential - the argument continues - to base the new morality not on fixed rules about actions, but on flexible standards concerned with the spirit in which those actions are planned.' This approach, he explained, 'has been taken up by some of the "South Bank" Anglicans', and was 'effectively presented' in 'Towards a Quaker View of Sex'. After rehearsing these ‘basically Christian’ moral arguments, Inglis attached them to a teleology: 'I have no doubt that this point of view will eventually prevail.' Even so, Inglis only provided a partial teleology of revolution, since he bemoaned the strength of establishment conservatism, and argued that 'a hard struggle lies ahead to get this point of view generally accepted’. 146

In April 1965, by contrast, the New Statesman ran a centrepiece by Malcolm Muggeridge entitled 'The sexual revolution', which argued that 'the sexual revolution... has 
actually happened'. Muggeridge’s article was part of his increasing fascination with religious themes, which culminated in his public reconversion to Christianity in 1969. Indeed, the article’s accompanying cartoon gently mocked him for this, portraying him holding a oneman demonstration in a church dressed up as a monk. ${ }^{147}$ Like Robinson, Muggeridge saw 'the sexual revolution' as a recent, inevitable, permanent, and pervasive development brought about by secularisation; unlike Robinson, he disliked it.

Muggeridge argued that western civilization had rejected Christianity because of the Bible’s ambivalence about material wealth, and that the sexual revolution was Christianity's replacement. It had its own 'prophets', 'teachers', and 'martyrs'; it was ultimately a 'cult of the orgasm'; it had replaced 'religion' as ‘the opium of the people'. Unlike Robinson, Muggeridge was geographically specific, arguing that Britain and the western world were following a modernizing trajectory which was best exemplified in America, although he did not acknowledge regional differences within any of these countries. Yet since Muggeridge viewed the 'sexual revolution' as an ersatz religion, he too argued that it was demographically total; sex now permeated 'every corner and cranny of life, from birth to grave', ensuring that, for Americans, 'dating begins at nine years old and even earlier'. He savagely mocked these apparent consequences of Christian decline, embedding his 'sexual revolution’ narrative in an eschatology of moral catastrophe. ${ }^{148}$

Another major discussion came in June 1965, when the Observer ran a series of four articles discussing 'the so-called sexual revolution of our times'. ${ }^{149}$ The first contributor was the journalist Katharine Whitehorn, who had a free-church family background; she was also the grand-daughter of A. Herbert Gray, the Scottish Presbyterian minister and marriage counsellor. ${ }^{150}$ Whitehorn began by declaring that she was 'unhesitatingly for the sexual revolution'; yet whilst she did not write from an explicitly religious perspective, her arguments drew heavily on discourses that had been developed by radical Christian writers, 
especially the authors of Towards a Quaker view of sex, which she singled out as 'one of the few things written on the subject' to be genuinely 'idealistic'. ${ }^{151}$ Echoing clerical commentators before her, she inferred a sexual revolution from the apparent collapse of religion, arguing that 'the old Christian prohibitions' were based on a 'doctrine' that 'only a fraction of people even understand, let alone believe'. She too imagined the 'sexual revolution' as pervasive and geographically universal, predicting that 'at the present rate of going, chastity will have died out altogether in another 50 years'. She too linked this revolution to the collapse of all moral rules, arguing that these days 'flat rules' would inevitably seem like 'a dry and pointless "no"'. Her central ethical argument, that 'chastity is not a matter of following rules but of caring enough about one relationship', was very similar that of Honest to God, which had argued that 'chastity is the expression of charity - of caring enough’ ${ }^{152}$ By contrast, the second contribution, from the novelist Penelope Mortimer, was much more cautious, arguing that whilst 'we are constantly being told these days that we are undergoing a sexual revolution', in fact 'the whole business seems to have lost touch with reality’. ${ }^{153}$ Yet the third commentator was Robinson himself, who extolled what he called ‘the sexual revolution in our time’ in much less careful language. As in Honest to God, he emphasized that this development brought freedom from inflexible rules, and freedom to enrich personal relationships. 'The Christian,' he concluded, 'has no need to fear the sexual revolution'. ${ }^{154}$

Following such media exposure, the ‘sexual revolution’ teleology rapidly entered British conventional wisdom. From the spring of 1965, the highbrow media increasingly dropped the phrase into articles without explanation or reference to religion. ${ }^{155}$ Perhaps not coincidentally, August 1965 saw the introduction of the miniskirt, ensuring that, for the first time, clothing frequently interpreted as visually symbolic of 'the sexual revolution' could be seen on Britain’s streets. ${ }^{156}$ The concept of 'the permissive society', which had initially 
attracted predominantly anti-authoritarian connotations, increasingly began to have sexual ones as well, and hostile references to 'permissiveness' in this double sense flourished during the 'law and order' debates of the 1970s and 1980s. ${ }^{157}$ Yet whilst Britain’s ‘sexual revolution’ narrative seemed by 1967 to be entirely secular, it still retained its original, theologically-inspired structural features, continuing in most instances to defy any attempt at sociological grounding by depicting 'the sexual revolution' as widespread, universal, antinomian, and inevitable. In June 1966, for example, a Times Literary Supplement article on 'the sex revolution' firmly stated that 'we are living now at some point - we cannot yet tell exactly where - in a revolution of attitudes towards sex', whilst leaving 'we' undefined. It conceptualized the revolution in terms of the 'admission' that 'sex' was 'an all-pervading part of life’, even implying that the narrative applied to young children. ${ }^{158}$ In April 1966, New York’s Time magazine deliberately looked to ‘Swinging London', which apparently symbolized a 'bloodless revolution' enveloping all of Britain, to lend legitimacy to sexual liberalisation in America. ${ }^{159}$ By October 1967 the teleology of sexual revolution was so firmly established in British discussion that the novelist and critic Margaret Drabble could begin an article on 'The sexual revolution' for the Guardian by declaring that 'it is no longer possible to deny that we face the certainty of a sexual revolution', which in her view would shortly be brought about by the pill. ${ }^{160}$ In the same year, the poet Philip Larkin famously wrote that 'sexual intercourse began/ in nineteen sixty-three'. Larkin's couplet had layers of meaning, but he had neatly encapsulated the now-conventional wisdom. ${ }^{161}$

The tabloid press were followers rather than leaders in the transformation of British sexual culture, but by the late 1960s they too had begun to repeat the teleology of widespread sexual liberalisation. ${ }^{162}$ In November 1967, for example, the journalist and novelist Keith Waterhouse announced in the Daily Mirror that the new generation's ‘sexual revolution... involves a change in thinking - a complete rejection of old values and the construction of 
new ones’. ${ }^{163}$ In April 1968 the People reported that Britain’s passion for striptease had sent it 'Strip crazy'. ${ }^{164}$ In September 1969 the journalist Rosalie Shann declared in the News of the World that 'we cannot halt the ever-growing permissive society'. ${ }^{165}$ Similarly, in November 1969 the newly relaunched Sun proclaimed that 'people who pretend that yesterday's standards are today’s’ are ‘living a lie’. 166

One of the immediate consequences of the authorization of the 'secularization' and ‘sexual revolution’ narratives was a transformation of who had the authority to speak publicly on sexual matters. In 1961, Teenage morals had included two clergymen amongst its six contributors; clergymen were present in the Guardian's 1965 four-part 'Living with sex' series, and in Sexual morality: three views (1965). Reviewing the last five years of the debate in their Adolescents and morality (1966), the sociologists Emanuel and May Eppel discussed religious contributions at length, focusing especially on Towards a Quaker view of sex, Robinson's Honest to God, and Rhymes’s No new morality. ${ }^{167}$ Eustace Chesser's Unmarried love (1965) also began its discussion by reviewing a range of religious contributions, positioning them as 'an indication of the winds of change'. ${ }^{168}$ In 1967, commenting from an American perspective, a Playboy editorial credited Honest to God with igniting 'Christianity's internecine battle over the updating of sexual morality', and then observed that 'the outcry about the Sexual Revolution, pro and con, soon escalated from obscure theological journals to the popular press'. ${ }^{169}$ As the 'secularization' narrative became widely accepted, however, clerical contributions were gradually reimagined as less important. From 1965 Christian commentators increasingly imagined themselves to be speaking in a newly post-religious context, producing titles such as John Robinson's Christian freedom in a permissive society (1970), William Barclay's Ethics in a permissive society (1971), and Peter Baelz’s Christian obedience in a permissive context (1973). These assumptions were also increasingly shared by the mainstream media. ${ }^{170}$ The Guardian's series on 'the permissive 
society', for example, printed in October 1967, included Robinson amongst its contributors, but placed him ninth in the series. ${ }^{171}$ Shortly afterwards, it published a list of seventeen 'priests and prophets of the permissive society'; despite the religious metaphor, none were clergymen. The sole religious figure was the heterodox visionary William Blake, who took his place beside Sigmund Freud, Bertrand Russell, Alex Comfort, the Beatles, the comedian Lenny Bruce, the playwright John Arden, and, remarkably, Fidel Castro. ${ }^{172}$ Since the revolution's reality and secularity were now taken for granted, it seemed entirely plausible to invoke such figures as symbols of an almost wholly secular teleology of sexual emancipation. ${ }^{173}$ In an imaginedly post-religious society, it was easy for Christian contributions to be forgotten. ${ }^{174}$

\section{V}

This rapid reimagination of British sexual mores, begun in 1963, well underway by 1965, and culturally dominant by 1967, was immediately followed by a real transformation of British sexual culture that has rightly been termed 'astonishing'. ${ }^{175}$ This section explores the connections between these two developments, using case-studies to argue that elite attempts to adapt to a newly reimagined sexual modernity played a major role in causing real sexual change. Other factors were undoubtedly involved: the legislative and cultural shifts of the late 1960s were partly generational, for example, and they also owed something to the supremacy of the Labour party in the House of Commons. Nonetheless, neither of these factors is sufficient to explain the speed with which the myth of 'the sexual revolution' was enacted. ${ }^{176}$ First, and perhaps most importantly, the narrative of widespread and inevitable sexual liberalization transformed the political debate about the provision of the pill to unmarried women. In the early 1960s, it was generally assumed that widespread such provision was 
outside the realm of political possibility. The early Brook clinics were deeply controversial. ${ }^{177}$ In June 1964 the AGM of the Family Planning Association amended out of existence a resolution to provide the pill to the unmarried, because it feared that this would be too contentious. ${ }^{178}$ A month earlier, the Conservative minister of health refused to give government funding to the FPA on the grounds that 'we must have some regard for public opinion, which is by no means unanimously in favour of this work' ${ }^{179}$ In February 1965, New Society reported that Labour's minister of health, Kenneth Robinson, had expressed interest in providing contraceptive advice on the NHS, 'but feels he must wait until the idea is more acceptable than it now is'. ${ }^{180}$ By 1967 , however, this assumption had been completely inverted. The Family Planning Act (1967), which permitted local authorities to supply the pill regardless of marital status, was waved through the Commons without serious opposition. ${ }^{181}$ Only one MP spoke against it, and was promptly ridiculed, and the measure passed without a division. ${ }^{182}$ During the debate it was stated, with widespread agreement, that 'no significant opposition to the Bill has been expressed today, and this is probably indicative of the mood for the country as a whole'. ${ }^{183}$ This was not in fact true: as noted earlier, in 1968 Gallup found that 49 per cent of its respondents disapproved of the use of contraception by the unmarried, outnumbering the 37 per cent who did approve. ${ }^{184}$ Nonetheless, the Family Planning Act was the crucial step towards making oral contraception widely available, and it became progressively so thereafter. ${ }^{185}$ As Hera Cook argues, the widespread availability of the pill was a central requirement for the widespread enactment of a real sexual revolution. ${ }^{186}$ Elite perceptions of popular sexual liberalization also provided an influential argument in favour of the increasingly frank depiction of sex in the mainstream media, a trend which accelerated dramatically from the mid-1960s. ${ }^{187}$ In the 1950 s the BBC's output had been a symbol of national respectability, but in 1965 its director-general, Hugh Carleton Greene, justified his changes to traditional BBC editorial policies by stating that 'we have a 
duty to take account of the changes in society, to be ahead of public opinion rather than always to wait upon it' ${ }^{188}$ This argument implicitly acknowledged the conservatism of public opinion whilst insisting on a teleology of sexual liberalization. 'Relevance is the key', he continued, 'relevance to the audience and to the tide of opinion in society'. ${ }^{189}$ Similar considerations underpinned the sudden relaxation of film censorship. In 1961 John Trevelyan, the secretary of the British Board of Film Censors, had restated his opposition to films featuring even the discussion of the purchase of contraceptives, and his leadership ensured that film censorship was relaxed only very slowly between 1958 and $1965 .{ }^{190}$ After 1965, however, he performed a volte-face, becoming a 'key figure' in the dramatic liberalization of film censorship in the late 1960s. ${ }^{191}$ 'The world is changing', he wrote in 1973, appealing to teleology to justify his record. 'What would have been accepted as logical and reasonable even ten years ago is now something that seems to belong to the past, not to the present, and certainly not to the future. ${ }^{, 192}$ He prefaced his memoirs with the declaration that 'times change and we change with them'. ${ }^{193}$ Similarly, despite what is often claimed of the Chatterley trial, which by 1969 barely registered in public consciousness, the major turning-point in literary decensorship did not occur until $1966 .{ }^{194}$ Parliament had actually tightened up the Obscene Publications Act in July 1964, but shortly afterwards the attempt to suppress mass-market softcore pornography was abandoned. ${ }^{195}$ The first 'recognizably modern’ pornographic magazines appeared in the winter of 1964, and rapidly secured an expanding market. ${ }^{196}$

Finally, and more speculatively, the authoritative dissemination of narratives of widespread sexual liberalization may well have had a directly transformative impact on popular behaviour. By the late 1960s, Hera Cook argues, 'many young women believed that a sexual revolution was taking place'. ${ }^{197}$ In 1970, as noted earlier, eighty per cent of NOP’s respondents agreed that 'people's attitudes towards sex in the last ten years have changed a 
lot' ${ }^{198}$ Not coincidentally, there was an 'explosion’ in pre-marital sex in the late 1960s and early 1970s. ${ }^{199}$ By redefining understandings of ‘normal’ sexual behaviour, by repositioning the boundaries of sexual deviance, and by creating a fear of missing out, the 'sexual revolution’ narrative very probably provided decisive encouragement for those who might otherwise have refrained. There is considerable anecdotal evidence of this effect, but further investigation will be needed to assess its pervasiveness. ${ }^{200}$

\section{VI}

This article has challenged the historiographical assumption that the British 'sexual revolution' was a natural consequence of social change, arguing that this assumption is a deeply influential cultural construction which dates from the early and mid-1960s. Instead, drawing on 'multiple modernities' theory and a determination to 'provincialize' British sexual culture, it has suggested that the British ‘sexual revolution’ should primarily be understood as an enacted narrative, invented and proclaimed from above, decisively legitimated between 1963 and 1967, and only widely acted upon thereafter. If 'sexual revolution’ narratives had failed to become authoritative, on this view, British sexual culture would have continued to evolve, but would not have undergone a rapid transformation. ${ }^{201}$ Only once MPs, cultural leaders, and ordinary people began to make their decisions in a reimagined social context could the long British sexual revolution really begin. ${ }^{202}$

This article has also suggested that the rise of Britain’s ‘sexual revolution’ narrative was shaped by Christian agency. Christian agency played an important role in framing postwar sexual change as a swift, widespread, unstoppable, post-religious, and antinomian revolution. It also played a significant if unwitting role in ensuring this narrative's rise to authority, not least by influentially reimagining Britain as a post-religious society in 1963 and 
1964, which was a necessary precondition of that rise. ${ }^{203}$ This initial importance of Christian agency was a natural consequence of the fact that clergymen enjoyed a dominant role in national discussions of sexual morality until 1963, and had a major although diminishing role into the mid-1960s. The conclusion that Britain’s ‘sexual revolution' narrative had important roots in Christian visions of rapid 'secularization' helps explain the timing of that narrative's rise to prominence, its early strategies of legitimation, the kinds of people who initially publicized it, its successful subversion of previously authoritative taboos, and its universalist narrative structure. It raises the possibility that teleologies of ever-increasing antinomianism derived from Christian eschatology were an important source of narratives of sexual transformation in postwar Britain, as they had been in pre-modern Europe. ${ }^{204}$

These arguments imply five wider points about the real transformation of British sexual culture from the late 1960s. First, they question the assumption that the British sexual revolution was essentially demotic. There was an unequal power relationship between metropolitan and provincial cultures; the sexual revolution was initially unpopular, and it progressed slowly and unevenly even within greater London, let alone the whole United Kingdom. ${ }^{205}$ Second, these arguments suggest that religious developments were central to the history of sex in 1960s Britain. They recast Christians as active and important agents in the construction of highly influential myths of rapid social change. ${ }^{206}$ These two points challenge Callum Brown's argument that a popular 'sexual revolution' caused the religious crisis of the 1960s, suggesting instead that the myth of religious collapse predated and authorized the myth of 'sexual revolution', not the other way around. ${ }^{207}$ Third, by privileging the transformation of dominant cultural narratives in the mainstream media, much of which was produced nationally rather than internationally or locally, this account has emphasized discursive change at national level. Even so, this transformation will need to be placed in its international context; in this respect, it is worth noting that narratives of religious crisis were 
a general western phenomenon during the 1960 s. ${ }^{208}$ Fourth, by privileging the role of contingent discursive shifts, these arguments reinforce the methodological presupposition that teleologies of sexual liberalisation invented in the mid-1960s should not be taken at face value. The rapid liberalisation of British sexual culture from the late 1960s was in no sense inevitable; overseas comparison suggests a range of alternative trajectories, from Singapore to Northern Ireland. ${ }^{209}$ Finally, and more widely, this article has privileged the Durkheimian theoretical presupposition that contemporary western societies are, like non-western societies, decisively structured by dominant underlying narratives, which are contingent cultural inventions. As with all other cultures in all other periods, there are good reasons for thinking that the Britons of the 1960s were primarily shaped, not by inexorable social forces, nor by specific ideologies, but by the stories they told about themselves. ${ }^{210}$

Lincoln College, Oxford, OX1 3DR; samuel.brewitt-taylor@lincoln.ox.ac.uk

* I am most grateful to Matthew Grimley, William Whyte, Alana Harris, Robert Saunders, Otto Saumarez Smith, this Journal's referees, and seminar participants at Oxford University and Plymouth University for their comments on this material, and to Lambeth Palace Library for permission to quote from the Robinson archive.

${ }^{1}$ For historiographical overviews, see C. Brown, 'Sex, religion, and the single woman c. 1950-75: the importance of a "short" sexual revolution to the English religious crisis of the sixties’, Twentieth Century British History, 22 (2011), pp. 189-215, at pp. 191-5; H. Cook, 'The English sexual revolution: technology and social change', History Workshop Journal, 59 (2005), pp. 109-28, at pp. 109-12; D. Herzog, 'Sexuality in the postwar west', Journal of Modern History, 78 (2006), pp. 144-71, especially p. 166.

2 J. Robinson, Honest to God (London, 1963), pp. 105, 118. 
${ }^{3}$ M. Muggeridge, 'The sexual revolution’, New Statesman, 2 Apr. 1965, p. 527; K.

Whitehorn et al., 'Living with sex’, Observer, 6 June 1965, p. 21; A. Bingham, Family newspapers? Sex, private life, and the British popular press 1918-1978 (Oxford, 2009), pp. 121-2; Cook, Long sexual revolution, p. 271.

${ }^{4}$ M. Collins, 'Introduction', in idem., ed., The permissive society and its enemies (London, 2007), pp. 1-40, at pp. 18-19.

${ }^{5}$ J. Weeks, The world we have won: the remaking of erotic and intimate life (London, 2007), p. 20; Cook, Long sexual revolution, p. 338; Brown, ““Short” sexual revolution’, pp. 194, 212; L. Hall, Sex, gender and social change in Britain since 1880 (Basingstoke, 2013), pp. 153, 163-4; C. Langhamer, ‘Adultery in post-war England’, History Workshop Journal, 62 (2006), pp. 86-115, at p. 110; A. Harris, Faith in the family: a lived religious history of English Catholicism, 1945-82 (Manchester, 2013), p. 162; D. Sandbrook, White heat: a history of Britain in the swinging sixties (London, 2006), pp. 464-5; N. Yates, Love now, pay later? Sex and religion in the fifties and sixties (London, 2010), p. 152; T. Newburn, Permission and regulation: law and morals in post-war Britain (London, 1992), p. 16. ${ }^{6}$ Cook, Long sexual revolution, p. 290; Brown, “"Short” sexual revolution’, p. 192. ${ }^{7}$ Pace Brown, 'Short sexual revolution’, pp. 196-7. Data from ibid., p. 199. As Hugh McLeod points out, these figures may not be reliable indicators of pre-marital sexual activity in any case, owing to the ready availability of condoms; ibid., p. 196, fn. 27.

${ }^{8}$ C. Langhamer, 'Love and courtship in mid-twentieth century England’, Historical Journal 50 (2007), pp. 173-96, at p. 178.

${ }^{9}$ J. Green, All dressed up: the sixties and the counter-culture (London, 1999), p. 86. See also the discussion of the Girton questionnaire in H. McLeod, The Religious Crisis of the 1960s (Oxford, 2007), pp. 165-6, although some of the activity reported by the cohort matriculating 
in 1961-2 may have taken place after 1965; 'Dean’s attack on sexual laxity’, The Times, 3 Feb. 1964, p. 7; 'Parents fear moral dangers at Oxford', Guardian, 29 Dec. 1964, p. 3.

${ }^{10}$ M. Schofield, The sexual behaviour of young people (London, 1965), p. 248; G. Gorer, Sex and marriage in England today (London, 1971), p. 30.

${ }^{11}$ Gallup, Great Britain 1937-1975, II, p. 1005.

${ }^{12}$ P. Barker and J. Hanvey, 'Facing two ways: between the 60s and the 70s', New Society, 27 Nov. 1969, pp. 847-50.

${ }^{13}$ Collins, 'Introduction’, pp. 18-19.

${ }^{14}$ C. Langhamer, ‘Adultery in postwar England’, History Workshop Journal 62 (2006), pp. 86-115, at p. 88.

${ }^{15}$ C. Langhamer, The English in love (Oxford, 2013), pp. 38-9, 151, 210.

${ }^{16}$ See for example K. Whitehorn et al., 'Living with sex’, Observer, 6 June 1965, p. 21.

${ }^{17}$ D. Herzog, 'Syncopated sex: transforming European sexual cultures', American Historical Review, 114 (2009), pp. 1287-308, at p. 1295. See for examples J. Weeks, Sex, politics, and society (London, 1989), pp. 249-50; H. Cook, 'The English sexual revolution: technology and social change’, History Workshop Journal, 29 (2005), pp. 109-28, at p. 124; C. Brown, 'What was the religious crisis of the 1960s?', Journal of Religious History, 34 (2010), pp. 468-79, at p. 478; Weeks, World we have won, p. 64.

${ }^{18}$ Herzog, ‘Syncopated sex’, p. 1295; see more generally D. Chakrabarty, Provincializing Europe: postcolonial thought and historical difference (Princeton, 2000).

${ }^{19}$ S. Eisenstadt, 'Multiple modernities', Daedalus, 129 (2000), pp. 1-3; V. Mackie and M. McLelland, 'Introduction: framing sexuality studies in East Asia', in idem., eds., Routledge handbook of sexuality studies in East Asia (London, 2014), pp. 1-17, at p. 3; J. Arnett, 'The cultural psychology of emerging adulthood', in L. Jensen, The Oxford handbook of human 
development and culture: an interdisciplinary perspective (Oxford, 2015), pp. 487-501, at pp. 492-3.

${ }^{20}$ J. Alexander and P. Smith, 'The discourse of American civil society: a new proposal for cultural studies', Theory and Society, 22 (1993), pp. 151-207, at p. 156; J. Alexander, The meanings of social life (Oxford, 2003), pp. 3-7, 13-14, 84; W. Sewell, Logics of history: social theory and social transformation (London, 2005), pp. 140-6, 151, 226-8. For this approach applied to sex, see the discussion of 'collective scenarios' in W. Simon and J. Gagnon, 'Sexual scripts: permanence and change’, Archives of Sexual Behaviour 15 (1986), pp. 97-120, at pp. 98-9.

${ }^{21}$ Alexander, Meanings of social life, pp. 3-4. For British examples of deeply-rooted norms, see R. McKibbin, Classes and cultures: England 1918-51 (Oxford, 1998), pp. 330-1; S. Szreter and K. Fisher, Sex before the sexual revolution: intimate life in England 1918-1963 (Cambridge, 2010), pp. 312-3.

${ }^{22}$ Sewell, Logics of history, pp. 244-6; Alexander, Meanings of social life, pp. 155-6.

${ }^{23}$ B. Czarniawska-Joerges, Narratives in social science research (London, 2004), pp. 3ff.

${ }^{24}$ Herzog, 'Syncopated sex’, p. 1295.

${ }^{25}$ T. Jones, 'Postsecular sex? Secularisation and religious change in the history of sexuality in Britain’, History Compass, 11 (2013), pp. 918-30, at pp. 920, 923.

${ }^{26}$ C. Brown, Religion and society in twentieth century Britain (Harlow, 2006), pp. 177-87; C. Field, 'Another window on British secularization: public attitudes to church and clergy since the 1960s’, Contemporary British History, 28 (2014), pp. 190-218, at p. 213; D. Kirby, 'Ecclesiastical McCarthyism: Cold War repression in the Church of England', Contemporary British History, 19 (2005), pp. 187-203, at p. 188.

${ }^{27}$ For theoretical context see Sewell, Logics of history, p. 257. 
${ }^{28}$ S. Brewitt-Taylor, ‘The invention of a "secular society”? Christianity and the sudden appearance of secularization discourses in the British national media, 1961-4', Twentieth Century British History, 24 (2013), pp. 327-50, at pp. 331-4, 340-4, 349.

${ }^{29}$ Mount to Robinson, 13 Dec. 1966, Lambeth Palace Library, Robinson papers, MS 3542, fo. 72 .

${ }^{30}$ Brewitt-Taylor, “Secular society”?’, pp. 329-30, 343-5. Tellingly, the major counterexample originated across the Atlantic: P. Halasz, 'You can walk across it on the grass', Time, 15 Apr. 1966, pp. 32-42.

${ }^{31}$ This transformation is described in Weeks, World we have won, pp. 15-20; Cook, Long sexual revolution, pp. 292-6.

${ }^{32}$ S. Szreter, 'Victorian Britain, 1837-1963: towards a social history of sexuality', Journal of Victorian Culture, 1 (1996), pp. 136-49; McKibbin, Classes and cultures, pp. 296-7, 330; M. Grimley, 'The religion of Englishness: puritanism, providentialism, and “national character”, 1918-1945', Journal of British Studies, 46 (2007), pp. 884-906, at pp. 896-8, 906; C. Brown, The death of Christian Britain: understanding secularisation, 1800-2000 (London, 2009), pp. 9, 170-5; B. Harrison, Seeking a role: England 1951-1970 (Oxford, 2009), pp. 506-12; Szreter and Fisher, Sex before the sexual revolution, pp. 384-5; A. Bingham, 'The K-Bomb: social surveys, the popular press, and British sexual culture in the 1940s and 1950s', Journal of British Studies, 50 (2012), pp. 156-79, at pp. 158, 161, 170.

${ }^{33}$ McKibbin, Classes and cultures, p. 330; Collins, 'Introduction’, pp. 6-7.

${ }^{34}$ J. Martin, 'Structuring the sexual revolution', Theory and society, 25 (1996), pp. 105-51, at pp. 106-7; Weeks, Sex, politics, and society (1989), pp. 154-6, 183-6.

${ }^{35}$ M. Collins, Modern love: an intimate history of men and women in twentieth-century Britain (London, 2003), pp. 90, 42, 48. 
${ }^{36}$ H. Cocks, 'Saucy stories: pornography, sexology, and the marketing of sexual knowledge in Britain, c. 1918-70’, Social History, 29 (2004), pp. 465-84, at p. 469; Szreter and Fisher, Sex before the sexual revolution, p. 113.

${ }^{37}$ P. Thane, 'Family life and “normality” in postwar British culture’, in R. Bessel and D. Schumann, eds., Life after death: approaches to a cultural and social history of Europe during the 1940s and 1950s (Cambridge, 2003), pp. 193-210, at pp. 198-9; Weeks, World we have won, p. 47; Langhamer, English in love, pp. 151, 179.

${ }^{38}$ Ibid., pp. 2-3, 6-7, 207-8; Collins, Modern love, p. 90; A. Harris, 'Love divine and love sublime? The Catholic marriage advisory council, the marriage guidance movement, and the state', in A. Harris and T. Jones, eds., Love and romance in Britain 1918-1970 (Basingstoke, 2014), pp. 188-224, at pp. 188-9.

${ }^{39}$ Langhamer, English in love, pp. 158-60; Collins, Modern love, pp. 93-4; Szreter and Fisher, Sex before the sexual revolution, pp. 312-3.

${ }^{40}$ K. Fisher, Birth control, sex, and marriage in England, 1918-1960 (Oxford, 2006), pp. $111-3$.

${ }^{41}$ Bingham, ‘The K-Bomb’, pp. 166, 178; Hall, Sex, gender, and social change, p. 146.

${ }^{42}$ Weeks, World we have won, pp. 39-47, 55.

${ }^{43}$ For this relationship, see Brown, ““Short” sexual revolution’, p. 212.

${ }^{44}$ L. Colley, Britons: forging the nation, 1707-1837 (London, 2003), pp. 368-9.

${ }^{45}$ C. Field, Britain's last religious revival? Quantifying belonging, behaving, and believing in the long 1950s (Basingstoke, 2015), p. 18.

${ }^{46}$ Field, ‘Another window on British secularization’, p. 213.

${ }^{47}$ S. Green, The passing of Protestant England: secularisation and social change c. 19201960 (Cambridge, 2011), pp. 33, 62-5; Brown, Religion and society in twentieth-century 
Britain (Harlow, 2006), p. 183; W. Pickering, 'The persistence of rites of passage: towards an explanation', British Journal of Sociology, 25 (1974), pp. 63-78, at p. 63.

${ }^{48}$ Gallup, Great Britain 1937-1975, I, p. 545; Brown, Death of Christian Britain, p. 192;

Kirby, ‘Ecclesiastical McCarthyism’, p. 188.

${ }^{49}$ Brewitt-Taylor, 'Invention of a “secular society”?’, p. 328.

${ }^{50}$ For the interwar assumption, see McKibbin, Classes and cultures, p. 330. For a 1960s

example, see E. and M. Eppel, Adolescents and morality (London, 1966), p. 6.

51 'Faith and morals’, Times Educational Supplement, 9 Nov. 1962, p. 607.

${ }^{52}$ E. Chesser, Is chastity outmoded? (London, 1960), pp. ix-xiv.

${ }^{53}$ Collins, Modern love, p. 173; Cook, Long sexual revolution, pp. 283-4.

${ }^{54}$ McLeod, Religious Crisis, pp. 84-99.

${ }^{55}$ P. Ferris, ‘The technology of faith’, Guardian, 28 Oct. 1962, pp. 22-3.

${ }^{56}$ A. Lunn and G. Lean, The new morality (London, 1964), pp. 132-3; Ferris, ‘Technology of faith’; C. Driver, ‘The morality of Harry Williams’, Guardian, 22 May 1963, p. 9.

${ }^{57}$ Quaker Home Service, Towards a Quaker view of sex (London, 1990, facsimile reprint of revised 1964 edition), p. 45.

${ }^{58}$ M. Roodhouse, 'Lady Chatterley and the monk: Anglican radicals and the Lady Chatterley trial of 1960', Journal of Ecclesiastical History, 59 (2008), pp. 475-500, p. 491. See for examples 'Yes, Christians ought to read it', Daily Mirror, 28 Oct. 1960, p. 7; 'Attempt to portray sex as “something sacred”', Times, 28 Oct. 1960, p. 6.

${ }^{59}$ G. Carstairs, This island now (London, 1962), p. 50.

${ }^{60} \mathrm{~J}$. Hampshire, 'The politics of school sex education policy in England and Wales from the 1940s to the 1960s', Social History of Medicine, 18 (2005), pp. 87-105, at p. 100; E. Chesser, Unmarried love (London, 1965), p. 20.

${ }^{61}$ Qu. in E. Patey, Young people now (London, 1964), p. 31. 
${ }^{62}$ Gallup, Great Britain 1937-1975, I, p. 700.

${ }^{63}$ Cook, Long sexual revolution, p. 286; M. Proops, ‘TV doctor’s amazing sex talk’, Daily Mirror, 15 July 1963, p. 24.

${ }^{64}$ M. Savage, 'Against epochalism: an analysis of conceptions of change in British sociology’, Cultural Sociology, 3 (2009), pp. 217-38, at p. 222-3; Brewitt-Taylor, “"Secular society”?', pp. 344-5. See for examples R. Hoggart, The uses of literacy (London, 1957), pp. 65-6; F. Zweig, The worker in an affluent society (London, 1961), p. 209.

${ }^{65}$ S. Middleton, ““Affluence” and the Left in Britain, c. 1958-1974', English Historical Review, 129 (2014), pp. 107-138, at p. 109.

${ }^{66}$ Jarvis, Conservative governments, pp. 30-2; Ministry of education, The youth service in England and Wales (London, 1960), pp. 15-19.

${ }^{67}$ See for examples A. Barton, 'Rough justice’, Guardian, 10 Apr. 1965, p. 8; 'Violence without motive', Times, 4 Aug. 1964, p. 9.

${ }^{68}$ Bingham, Family newspapers, pp. 118-120.

${ }^{69} \mathrm{Qu}$. in S. Maclure, 'Teenage morals in an age of uncertainty', in S. Maclure et al., Teenage morals (London, 1961), pp. 4-10, esp. pp. 4-5.

${ }^{70}$ D. Eccles, 'Foreword', in ibid., inside cover.

${ }^{71}$ Ibid., p. 2.

${ }^{72}$ Ibid., p. 3; Maclure, 'Teenage morals’, p. 10; G. Gorer, 'Anthropologist', in ibid., pp. 1113, at p. 13.

${ }^{73}$ W. Watson, 'Sociologist', in ibid., pp. 19-21, at p. 19.

${ }^{74}$ L. Weatherhead, 'A nation in danger', Times, 20 Sept. 1961, p. 13; for a summary of responses, see A. Vidler, 'Religious belief today and its moral derivatives’, in W. Niblett, ed., Moral education in a changing society (London, 1963), pp. 78-95, at pp. 81-2.

${ }^{75}$ Carstairs, This island now, p. 51. 
${ }^{76}$ B. Wootton, 'What would Lord Reith say?’, Guardian, 16 Dec. 1962, p. 9.

77 A. Halsey, 'Another island', Guardian, 17 May 1963, p. 7.

${ }^{78}$ G. Carstairs, 'People bite professor', New Society, 30 May 1963, pp. 23-4.

${ }^{79}$ Ibid., p. 24.

80 'How the U.S. sees Britain's “barrage of frankness about sex”', Evening Standard, 21 Mar. 1963, p. 7. See for examples ‘Are virgins obsolete?’, New Statesman, 4 Jan. 1963, pp. 8-9;

Bingham, Family Newspapers, p. 120; Cook, Long sexual revolution, pp. 283-4.

${ }^{81}$ F. Mort, Capital affairs: London and the making of the permissive society (London, 2010), pp. 332-3.

${ }^{82}$ J. Freeman, ‘A time for austerity’, Queen, 25 Sept. 1963, p. 67; qu. in Mort, Capital affairs, p. 332.

83 'Refuge for illegitimates', New Society, 19 Dec. 1963, pp. 19-20.

${ }^{84}$ See for example W. Young, 'VD and doctors', Guardian, 11 Mar. 1964, p. 20.

${ }^{85}$ Brewitt-Taylor, ““Secular society”?’, pp. 340-3.

${ }^{86}$ Brown, Death of Christian Britain, p. 9.

${ }^{87}$ E. James, 'Robinson, John Arthur Thomas (1919-83)’, Oxford Dictionary of National Biography. See for examples 'I believe, or not as the case may be', Private Eye, 5 Apr. 1963, p. 7; M. Furlong, 'The bishop of Woolwich', Punch, 20 May 1964, pp. 732-4; Flanders and Swann, 'All gall', At the Drop of (Another) Hat (1964), 2'32ff; J. Gould, Can't buy me love: The Beatles, Britain and America (London, 2007), p. 346; K. Mouat, 'Theological striptease’, Oz 1, Feb. 1967, pp. 13, 17.

${ }^{88}$ J. Robinson, 'The debate continues', in D. Edwards, ed., The Honest to God debate (London, 1963), pp. 232-75, at p. 232n.

${ }^{89}$ Robinson, Honest to God, p. 105.

${ }^{90}$ E. James, A Life of Bishop John A. T. Robinson (London, 1987), p. 169. 
91 J. Robinson, 'Our image of God must go’, Observer, 17 Mar. 1963, p. 21.

92 Robinson, Honest to God, p. 105.

${ }^{93}$ Ibid., p. 118.

${ }^{94}$ Ibid., pp. 116, 120-1.

${ }^{95}$ J. Robinson, Christian freedom in a permissive society (London, 1970), pp. 49-50.

${ }^{96}$ J. Robinson, On being church in the world (Harmondsworth, 1969), p. 8; Robinson,

Christian freedom in a permissive society, pp. 130, 240; J. Robinson, The New Reformation? (London, 1965), pp. 51-2.

${ }^{97}$ Robinson, Honest to God, pp. 130-1. This assumption was famously challenged by Michel Foucault’s History of Sexuality (1976); Collins, 'Introduction’, 34.

${ }^{98}$ Robinson, Honest to God, p. 104.

${ }^{99}$ See for example Weatherhead, 'Nation in danger', Times, 20 Sept. 1961, p. 13; contrast Robinson, Honest to God, p. 117.

${ }^{100}$ Ibid., p. 105.

${ }^{101}$ Martin, 'Structuring the sexual revolution’, p. 132; Robinson, Honest to God, p. 115.

${ }^{102}$ S. Todd and H. Young, 'Baby-boomers to "beanstalkers”: making the modern teenager in postwar Britain', Cultural and Social History, 9 (2012), pp. 451-67, at pp. 451-3.

${ }^{103}$ D. Fowler, Youth culture in modern Britain c. 1920-c. 1970 (Basingstoke, 2008), p. 173;

G. Mitchell, ‘Reassessing “the generation gap”: Bill Haley’s 1957 tour of Britain, intergenerational relations, and attitudes to rock 'n' roll in the late 1950s', Twentieth Century British History, 24 (2013), pp. 573-605, esp. pp. 576, 585.

${ }^{104}$ A. Marwick, The sixties: cultural revolution in Britain, France, Italy, and the United States, c. 1958-c.1974 (Oxford, 1998), p. 75.

105 J. Green, All dressed up: the sixties and the counterculture (London, 1990), p. 86. 
${ }^{106}$ Marwick, The sixties, p. 466; M. Collins, ‘The pornography of permissiveness: men’s sexuality and women’s emancipation in mid twentieth-century Britain’, History Workshop Journal, 47 (1999), pp. 99-120, n. 1.

${ }^{107}$ Yates, Love now, pay later?, p. 80.

${ }^{108}$ McLeod, Religious crisis, p. 163. G. Tindall, 'Magazine morality’, Guardian, 21 Oct. 1966, p. 8.

${ }^{109}$ Bingham, Family newspapers, pp. 219-21.

110 J. McAleer, Passion's fortune: the story of Mills and Boon (Oxford, 1999), pp. 258, 274.

${ }^{111}$ C. Brown, "The "unholy Mrs Knight” and the BBC: secular humanism and the threat to the “Christian nation”, c. 1945-1960’, English Historical Review, 127 (2012), pp. 345-76, at pp. 349-50. For examples, see J. Priestley, 'Random reflections on sex’, New Statesman, 23 Aug. 1963, pp. 222-4, at p. 224; A. Miles, 'Verdict on the leaders of tomorrow', Daily Express, 2 Dec. 1963, p. 25.

${ }^{112}$ For an overview see McLeod, Religious crisis, pp. 83-90.

113 There was already a considerable Christian tradition of asserting the secularisation narrative. Brewitt-Taylor, ““Secular society”?’, pp. 337-43.

${ }^{114}$ J. Wren-Lewis, 'The passing of puritanism', Listener, 30 Jan. 1964, pp. 175-6.

${ }^{115}$ R. Lloyd, The ferment in the church (London, 1964), p. 102.

${ }^{116}$ D. Rhymes, No new morality: Christian personal values and sexual morality (London, 1964), pp. 19, 29-30.

${ }^{117}$ James, Life of Robinson, p. 78.

${ }^{118}$ Rhymes, No new morality, pp. 19, 29, 46, 48.

${ }^{119}$ Ibid., p. 51. 
${ }^{120}$ See for examples ‘Ease sex “code”, says canon’, Daily Mirror, 11 Mar. 1963, p. 10;

'Canon seeks new moral code’, Daily Express, 11 Mar. 1963, p. 11; 'Summary of the news’, Church Times, 15 Mar. 1963, p. 3; Lunn and Lean, The new morality, p. 133.

121 'Note of fear from noisy moralists', Times, 26 Feb. 1965, p. 7.

${ }^{122}$ D. Goodhew, 'Introduction', in idem., ed., Church growth in Britain: 1980 to the present (Farnham, 2012), pp. 3-22, at p. 19.

${ }^{123}$ P. Howard, Britain and the beast (London, 1963), p. 55.

${ }^{124}$ G. Bentley, God and Venus: an essay on sex (London, 1965), pp. 4, 9.

${ }^{125}$ G. Bentley, 'The new morality: a Christian comment', in R. Sadler, ed., Sexual morality: three views (London, 1965), pp. 33-61, at pp. 39-40.

${ }^{126}$ See for examples 'Morals: bishop tells of church’s neglect’, Daily Express, 5 July 1963, p. 5; ‘The defenders’, Daily Express, 9 Sept. 1963, p. 8; 'Morality: “Army” general hits at new evils’, Daily Express, 1 Nov. 1963, p. 16.

${ }^{127}$ Harris, Faith in the family, pp. 159-69.

${ }^{128}$ Newburn, Permission and regulation, pp. 18-9.

${ }^{129}$ J. Pilger, 'Face to face’, Daily Mirror, 29 Nov. 1965, pp. 16-17.

${ }^{130}$ Weeks, Sex, politics, and society (1989), pp. 253-4; 'Refuge for illegitimates’, New Society, 19 Dec. 1963, pp. 19-20; 'Sex and young people', New Society, 30 Sept. 1965, p. 23. ${ }^{131}$ G. Godber, The health of the school child, 1960 and 1961 (London, 1962); qu. in E. Eppel, 'The adolescent and changing moral standards', in Niblett, Moral education, pp. 11237, at p. 117.

${ }^{132}$ R. Fletcher, ‘A humanist’s decalogue’, New Society, 2 May 1963, pp. 17-20, at pp. 19, 17. 133 A. McGlashan, 'Sex on these islands', Encounter, July 1963, pp. 100-4, at p. 101. ${ }^{134}$ Cook, Long sexual revolution, pp. 286-7. 
${ }^{135}$ A. Comfort, Sex in society (London, 1964), pp. 99-101; Weeks, Sex, politics and society (1989), p. 253.

${ }^{136}$ A. Comfort, 'Of lustinesse’, Guardian, 30 July 1965, p. 7.

${ }^{137}$ M. Laski, 'Facts of life’, Guardian, 25 July 1965, p. 3.

${ }^{138}$ K. Whitehorn et al., 'Living with sex’, Observer, 6 June 1965, p. 21; W. Young, Eros denied (London, 1965), p. 13.

${ }^{139}$ Chesser, Unmarried love, pp. 25-7.

140 'Symposium’, Penthouse, Mar. 1965, pp. 11-14, at p. 12.

${ }^{141}$ D. Sandbrook, Never had it so good: a history of Britain from Suez to the Beatles (London, 2006), pp. 106, 433ff, 517ff.

${ }^{142}$ See for examples 'Morals: the second sexual revolution', Time, 24 Jan. 1964, pp. 42-7;

‘Sexplosion’, Christian Century, 29 Jan. 1964, pp. 136-8.

${ }^{143}$ Brewitt-Taylor, ““Secular society”?’, p. 331.

${ }^{144}$ For context, see M. Collins, 'Pornography of permissiveness’, p. 99. The Pirelli calendar was not a magazine.

${ }^{145}$ B. Inglis, 'Sex and society in the sixties’, King, Winter 1964, pp. 11-15.

${ }^{146}$ Ibid., p. 15.

${ }^{147}$ P. Phillips, Contesting the moral high ground: popular moralists in twentieth-century Britain (Montreal, 2013), pp. 110-16; I. Hunter, Malcolm Muggeridge: a life (London, 1980), pp. 219-20. New Statesman, 2 Apr. 1965, p. 517.

${ }^{148}$ M. Muggeridge, ‘The sexual revolution’, ibid., p. 527.

${ }^{149}$ Whitehorn et al., 'Living with sex', Observer, 6 June 1965, p. 21, and Observer, 13 June 1965, p. 21.

${ }^{150}$ K. Whitehorn, Selective memory: an autobiography (London, 2007), pp. 3, 12-3.

${ }^{151}$ Whitehorn, 'Living with sex'. 
${ }^{152}$ Robinson, Honest to God, p. 119.

${ }^{153}$ P. Mortimer, 'Living with sex’, Observer, 6 June 1965, p. 21.

${ }^{154}$ Robinson, 'Living with sex'.

${ }^{155}$ See for examples B. Alan, ‘Afterthought’, Spectator, 30 Apr. 1965, p. 581; ‘Lessons for writers', Times Literary Supplement, 29 June 1965, p. 331; 'Break-through for birth control', Economist, 29 May 1965, p. 1036; M. Tippett, ‘The BBC’s duty to society’, Listener, 26 Aug. 1965, p. 302; 'Dreams and responsibilities’, TLS, 30 June 1966, p. 575; C. King, 'The British press: a Financial Times survey’, Financial Times, 25 July 1966, p. 1; T. Szamuely, 'S*x behind the curtain', Spectator, 12 Aug. 1966, p. 200.

${ }^{156}$ Marwick, The sixties, p. 466.

${ }^{157}$ See for examples P. Mortimer, 'Living with sex’, Observer, 6 June 1965, p. 21; ‘Mere anarchy or new freedom?', Guardian, 7 Oct. 1967, p. 1. Weeks, Sex, Politics, and Society (1989), p. 249; see for example 'Tories will campaign on law and order', Observer, 1 Feb. 1970, p. 1.

${ }^{158}$ C. Peters, 'The sex revolution', TLS, 30 June 1966, p. 577.

${ }^{159}$ L. Grant, Sexing the millennium: a political history of the sexual revolution (London, 1993), pp. 85-6.

${ }^{160}$ M. Drabble, ‘The sexual revolution’, Guardian, 11 Oct. 1967, p. 8.

${ }^{161}$ P. Larkin, Collected poems: edited with an introduction by Anthony Thwaite (London, 2003), pp. 146, 207.

${ }^{162}$ A. Bingham and M. Conboy, Tabloid century: the popular press in Britain, 1896 to the present (Oxford, 2015), p. 155; Bingham, Family newspapers, pp. 121-2.

${ }^{163}$ K. Waterhouse, ‘The cool four million’, Daily Mirror, 29 Nov. 1967, p. 14.

${ }^{164}$ People, 14 April 1968, p. 1; qu. in Bingham, Family newspapers, p. 122.

${ }^{165}$ News of the World, 28 Sept. 1969, p. 14; qu. in Bingham, Family newspapers, p. 122. 
${ }^{166}$ Sun, 22 Nov. 1969, p. 2; qu. in Bingham, Family newspapers, p. 122.

${ }^{167}$ Eppel and Eppel, Adolescents and morality, pp. 14-18.

${ }^{168}$ Chesser, Unmarried love, pp. 11-21.

169 'Playboy panel: religion and the new morality: leading liberals of the clergy debate the church’s role in today’s sexual revolution', Playboy, June 1967, pp. 55-78, at p. 56.

${ }^{170}$ Brewitt-Taylor, ““Secular society”?’, p. 347.

${ }^{171}$ Sidenote to J. Wilson, 'What kind of morality?’, Guardian, 25 Oct. 1967, p. 8.

172 'Priests and prophets of permissiveness', Guardian, 12 Oct. 1967, p. 9.

${ }^{173}$ As it has seemed since: Szreter and Fisher, Sex before the sexual revolution, pp. 48-9.

${ }^{174}$ As Timothy Willem Jones observes, this forgetfulness is also a feature of later historiography: Jones, Sexual politics in the Church of England, pp. 6-7.

${ }^{175}$ Cook, Long sexual revolution, pp. 292-3.

176 Thompson, ‘Labour’s “Gannex conscience”? Politics and popular attitudes in the “permissive society”', in R. Coopey et al., eds., The Wilson Governments 1964-70 (London, 1993), pp. 140-1.

${ }^{177}$ Cook, Long sexual revolution, pp. 288-90.

${ }^{178}$ A. Leathard, The fight for family planning: the development of family planning services in Britain, 1921-74 (London, 1980), p. 139.

179 ‘Family planning association’, House of Commons Debates, 4 May 1964, vol. 694, cc. 880-1, c. 881.

180 'Prevention as cure', New Society, 11 Feb. 1965, p. 3.

${ }^{181}$ S. Brooke, Sexual politics: sexuality, family planning and the British left from the 1880s to the present day (Oxford, 2011), p. 175; Leathard, Family planning, p. 135.

${ }^{182}$ See Leo Abse’s comments in 'National Health Service (Family planning bill)', House of Commons Debates, 17 Feb. 1967, vol. 741, cc. 935-1020, с. 961. 
${ }^{183}$ Ibid., c. 996.

${ }^{184}$ Gallup, Great Britain, 1937-75, II, p. 1005.

${ }^{185}$ Leathard, Family planning, p. 144.

${ }^{186}$ Cook, Long sexual revolution, p. 295.

${ }^{187}$ Ibid., p. 293.

${ }^{188}$ Brown, “"The unholy Mrs Knight”', pp. 351-5. H. Greene, The third floor front: a view of broadcasting in the sixties (London, 1969), p. 101.

${ }^{189}$ Ibid., p. 103.

190 A. Aldgate, Censorship and the permissive society: British cinema and theatre, 1955-1965 (Oxford, 1995), p. 147.

${ }^{191}$ Ibid., pp. 5, 151-2.

192 J. Trevelyan, What the censor saw (London, 1973), p. 19.

193 Ibid., title page; qu. Aldgate, Censorship and the permissive society, p. 5.

${ }^{194}$ D. Sutherland, Offensive literature: decensorship in Britain, 1960-82 (London, 1982), p.

2; Barker and Hanvey, 'Facing two ways', p. 848, table 2.

${ }^{195}$ Collins, 'Pornography of permissiveness’, p. 103.

${ }^{196}$ Ibid., p. 100.

${ }^{197}$ Cook, Long sexual revolution, p. 271.

${ }^{198}$ Collins, 'Introduction’, pp. 18-19.

${ }^{199}$ Brown, ““Short” sexual revolution’, p. 212.

${ }^{200}$ G. De Groot, The sixties unplugged (Basingstoke, 2009), pp. 218ff; Langhamer, 'Adultery in post-war England', p. 107.

${ }^{201}$ For this transformation, see Cook, Long sexual revolution, pp. 292-5.

${ }^{202}$ For the long post-1960s sexual revolution, see Weeks, World we have won, pp. 14-22, 5763. 
${ }^{203}$ Brewitt-Taylor, 'Invention of a “secular society”?’, pp. 340-4.

${ }^{204}$ For early modern context see N. Cohn, The pursuit of the millennium: revolutionary millenarians and mystical anarchists of the middle ages (London, 2004), pp. 148-51, 176-80; M. Weisner-Hanks, Christianity and sexuality in the early modern world: regulating desire, reforming practice (London, 2000), pp. 65-6; Grant, Sexing the millennium, pp. 23-28, 39-40. ${ }^{205}$ Brooke, Sexual politics, p. 148.

${ }^{206}$ Pace Brown, Death of Christian Britain, p. 176.

${ }^{207}$ Pace Brown, ““Short” sexual revolution’, pp. 193-5.

${ }^{208}$ Herzog, ‘Syncopated sex’, pp. 1298-9; McLeod, Religious crisis, pp. 1-2.

${ }^{209}$ Herzog, ‘Syncopated sex’, pp. 1295-7, 1300-1; L. Leong, ‘Asian sexuality or Singapore exceptionalism?', Liverpool Law Review 33 (2012), pp. 11-26, at p. 15; C. Brown, Religion and the demographic revolution: women and secularisation in Canada, Ireland, UK and USA since the 1960s (Woodbridge, 2012), p. 134.

${ }^{210}$ Alexander and Smith, 'New proposal for cultural studies', p. 156; Alexander, Meanings of Social Life, pp. 3-5. 